Borowski-Beszta, M., \& Kiermas, A. (2019). The usage of mobile banking applications in Poland: empirical results. Copernican Journal of Finance \& Accounting, 8(1), 9-25. http://dx.doi. org/10.12775/CJFA.2019.001

\author{
Mikolaj BorowsKi-Beszta* \\ Nicolaus Copernicus University in Toruń
}

\author{
Anna Kiermas** \\ Nicolaus Copernicus University in Toruń
}

\title{
THE USAGE OF MOBILE BANKING APPLICATIONS IN POLAND: EMPIRICAL RESULTS
}

Keywords: mobile banking, mobile applications, payment services.

J E L Classification: D12, E42, 033.

Abstract: The purpose of this article is to determine the scope of mobile banking applications use among retail bank customers in Poland. A brief review of different approaches to the mobile banking definition is presented, and the definition that corresponds to the current state of the mobile banking market has been pointed out. The paper also presents the evolution and development of mobile banking channel in Poland in the years 2000-2018. The number of active mobile banking users in the years 2014-2018

Date of submission: May 27, 2019; date of acceptance: June 1, 2019.

* Contact information: mikolaj.borowski.beszta@gmail.com, Faculty of Economic Sciences and Management, Nicolaus Copernicus University in Toruń, Gagarina 13a, 87-100 Toruń, Poland, phone: +48 698700 010; ORCID ID: https://orcid.org/00000001-6590-4279.

** Contact information: anna.kiermas@gmail.com, Faculty of Economic Sciences and Management, Nicolaus Copernicus University in Toruń, Gagarina 13a, 87-100 Toruń, Poland, phone: +48 533643 552; ORCID ID: https://orcid.org/0000-0002-6876-9866.

This work was supported by the National Science Centre, Poland under Grant No. 2017/26/E/HS4/00858. 
has dynamically increased from 3.5 in 2014, to over 11.2 million in 2018, which is much faster than the development of online banking. The quantitative study is based on a survey performed in 2018 with the use of the CAWI method, carried on a representative sample of 1012 Polish Internet users. The obtained results allow to explore the customers' usage of mobile banking applications. It turned out, that these applications are already a popular communication channel among Polish Internet users - over half of respondents already have a mobile banking application installed on their device and $3 / 4$ of them use it on a day-to-day basis. The most common functions are checking the account balance or initiating a bank transfer. Furthermore, nine of ten users are satisfied with the use of their application. The results also suggest, that due to growing needs of mobile banking applications users, as well as the increasing usefulness and ergonomics of applications, the upward trend of mobile banking applications usage in Poland is not likely to slow down in the next few years.

\section{INTRODUCTION}

Mobility is currently an extremely valued and sought-after feature in many areas of the economy and private life. It is associated with: convenience, quickness, and above all the ability to perform specific activities anywhere and at any time (Sobiesiak \& Zagrodniczek, 2018, p. 66). In banking, mobility manifests itself through innovative channels of communication between the bank and its clients. When the first mobile banking solutions have been introduced in Poland at the beginning of the 21st century, there was a shortage of adequately advanced technology that would be sufficiently effective and accessible to the majority of the population (Polasik, 2013, pp. 146-148). This stems from the fact that mobile banking was and still is closely related to the development and access to new technologies, i.e. hardware and system solutions that create opportunities for the development of a mobile channel of interaction with the bank (Kuchciak, 2012, pp. 477-478). Internet banking in Poland is functioning since the end of the nineties, (Wojtacka-Pawlak, 2015, p. 156), however, during the next 10 years, its popularization on mobile devices was constricted because it required a user-friendly interface. After many unsuccessful attempts, the breakthrough moment for mobile banking in Poland came in 2009, along with the popularization of mobile application technologies and its implementation in the area of banking item. Together with growing interest in using mobile banking services among consumers, more and more banks began to offer mobile applications developed especially for this purpose (Bolibok \& Matras-Bolibok, 2014, pp. 9-10). Currently, smartphones and other mobile devices are characterized by high availability on the market, and their popularization along with expansion of the mobile Internet is generating huge potential for the 
development of mobile banking. It is therefore reasonable to examine the present role of this communication channel in the provision of banking services in Poland.

\section{THE RESEARCH METHODOLOGY AND THE COURSE OF THE RESEARCH PROCESS}

The purpose of this article is to determine the scope of use of mobile applications by retail banking customers in Poland. This paper addresses the following research questions:

- How popular are mobile banking applications and how often they are used by customers?

- Which banking services are performed by mobile banking applications?

- How Internet users perceive mobile banking applications and what is the level of their satisfaction?

The theoretical part of this article is based on Polish and foreign subject literature as well as numerous professional expert studies, including reports from the Polish Bank Association and the industry portal PRNews.pl. The empirical part of this paper, including the analysis of the use and perception of mobile banking applications, is based on the results of own survey study, which questionnaire was elaborated with the use of the Technology Acceptance Model research framework (Davis, 1989). The survey was carried out by CAWI (Computer Assisted Web Interview) method in December 2018 on a sample of 1012 Polish Internet users. The selection of the sample and the process of collecting the responses were conducted within a dedicated system by the IRCenter agency. There was a random selection of respondents and the study is representative on a national scale in terms of gender, age, and place of residence.

\section{MOBILE BANKING}

Mobile banking, gaining very fast popularity on the Polish payment services market, has been characterized by many specialists who in their definitions chose different approaches to the issue. According to K. Zarańska and M. Zborowski (2018, p. 18), "mobile banking, abbreviated as m-banking, could be defined as the use of banking services with the aid of mobile devices, i.e. smartphones or tablets". I. Kuchciak (2012, p. 470) notes further that "mobile banking is currently the most modern approach to the provision of banking services, integrating the bank with telecommunications services." In addition, 
mobile banking is "one such convergence service that brings together hitherto unconnected industries - banking and mobile operators - to offer value added services to their respective customers" (Lee, Harindranath, Oh \& Kim, 2015, p. 552), moreover "the application itself can completely replace banking operations performed using a classic browser" (Zakonnik \& Dembowski, 2018, p. 109). From the bank's perspective, through the introduction of mobile banking services, banks want to provide the client with a better and more effective communication channel (Alalwan, Dwivedi, Rana \& Williams, 2016, p. 118). For banks the additional advantage of mobile banking is the ability of sending personalized product offers or conducting other promotional campaigns that strengthen the client's affiliation to a given bank (Bolibok \& Matras-Bolibok, 2014, p. 16).

For the purpose of this publication, the authors adopted the definition of mobile banking, given by A. A. Shaikh and H. Karjaluoto (2015, p. 130): "A product or service offered by a bank or a microfinance institute (bank-led model) or MNO (non-bank-led model) for conducting financial and non-financial transactions using a mobile device, namely a mobile phone, smartphone, or tablet."

Mobile banking has many features among which there could be distinguished both positive and negative ones. The table 1 lists the particular advantages and weaknesses of mobile banking, developed on the basis of the available literature on the subject. In addition, the advantages and weaknesses are selected according to the benefits of customers and banks.

Mobile banking is characterized by high comfort of use, what is more, the number of functionalities available for the customer is constantly increasing. The security level of mobile banking applications and IT systems is also rising, so the risk of potential fraud is being reduced. In the above table, the number of advantages significantly exceeds the number of weaknesses, so it can be concluded that mobile banking is a beneficial communication channel for both customers and banks.

The application of innovative solutions has contributed to the expansion of the mobile banking channel, which is currently considered the most important channel of accessing banking services, and the constantly growing interest in mobile banking offers determines the increase in the pace of development of the analyzed method of banking and perpetually widening range of banking services provided by the mobile channel (Bolibok \& Matras-Bolibok, 2014, p. 8; Krzysztoszek, 2017, pp. 6-7). 
Table 1. The mobile banking main advantages and weaknesses from the customer and the bank perspective

\begin{tabular}{|c|c|c|c|}
\hline \multicolumn{2}{|c|}{ Advantages } & \multicolumn{2}{|c|}{ Weaknesses } \\
\hline For customer & For bank & For customer & For bank \\
\hline 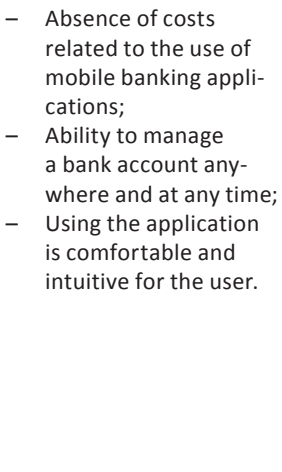 & 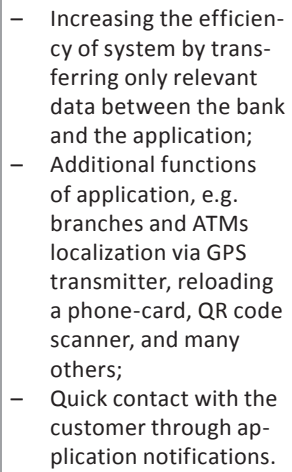 & $\begin{array}{l}\text { - The risk of a potential } \\
\text { Cyber-attack. }\end{array}$ & 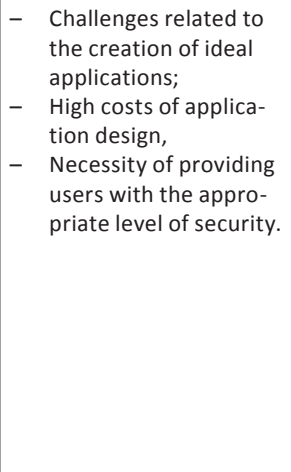 \\
\hline
\end{tabular}

S o u r c e : own study based on: (Polasik, 2013; Bolibok \& Matras-Bolibok, 2014).

\section{The BeginNings of MOBILE BANKING IN Poland}

Mobile banking entered the Polish payment services market in 2000, when the Bank Zachodni WBK launched the SMS information service. This service offered information about the balance and the last five transactions carried out on the customer's account, provided that its owner mobile phone operated in the Plus GSM network. The BZ WBK was also the first bank in Poland to launch a mobile site operating in the WAP (Wireless Application Protocol) protocol. Shortly after, the same solution was offered by mBank. At that time there were high expectations of WAP technology, as well as very enthusiastic opinions of experts who claimed that this technology is able to become the main channel of communication between the customer and the bank. WAP, however, did not arouse much interest among customers, and among main reasons were high rates of accessing the Internet via mobile phone. In 2002, the Raiffeisen Bank and the Inteligo offered a similar solution, developed in the newer WAP 2.0 protocol (Bolibok \& Matras-Bolibok, 2014, pp. 9-10; www1). Moreover, the Inteligo, as the first institution in Poland, launched the "I pay with SMS" service in the SIM Toolkit (STK) system, which allowed to perform particular banking operations, such as making transfers, managing deposits, paying off debts or searching for nearby ATMs (Sobiesiak \& Zagrodniczek, 2018, p. 67; www5). With time, more 
and more banks launched SMS services. In 2005, the Bank Millenium launched SMS notifications, and a year later, the mBank, the Multi Bank, the Citi Handlowy, and the ING Bank Śląski introduced, used until today, the one-time SMS passwords sent for the purpose of one-time authorization of an online transaction, e.g. a bank transfer (Hassa, 2013). Unfortunately, for the next three years, the development of mobile banking slowed down because WAP solutions, SIM Toolkit and SMS banking did not become popular, and the primary reason for this was a failure in meeting customers' expectations (www1). Only in 2008, when the Inteligo introduced the first version of light website - adapted especially for mobile devices (Bolibok \& Matras-Bolibok, 2014, p. 13), the mobile banking market has been stimulated (Hassa, 2013, p. 42). Soon thereafter, various banks introduced mobile applications in their offer, thus making a new attempt to develop a mobile communication channel between the customer and the bank in terms of available functionalities, as well as their suitability and ease of use (Sobiesiak \& Zagrodniczek, 2018, p. 67)

\section{THE DEVELOPMENT OF MOBILE BANKING IN POLAND}

One of the key elements that contributed to the dynamic development of mobile banking in Poland is development of mobile banking applications that have quickly gained recognition among individual customers. The first mobile application was launched in 2009, and it swiftly obtained the status of the most advanced mobile banking solution (Bolibok \& Matras-Bolibok, 2014, pp. 9-10). At the same time, along with mobile applications, so-called light versions of websites emerged, however, the ergonomics of using that website via the mobile device browser was unsatisfactory, moreover, in comparison to mobile websites, mobile applications were characterized by a higher level of security (Polasik, 2013, pp. 146-147; Kuchciak, 2012 p. 472; Kaczmarek, 2018, p. 147).

The available back then generations of mobile phones did not meet the technical requirements, which was somehow constraining the development of mobile banking applications (Bolibok \& Matras-Bolibok, 2014, pp. 9-10). But when the availability of smartphones increased on the market and the vendors of mobile networks significantly reduced the costs of Internet data transfer, mobile devices became tools for the consumption of goods and services (Kaczmarek, 2018, p. 146). The smartphones have become bearers of new functionalities - from now on these devices could be used not only for making calls, sending 
messages or using the Internet, but also for financial purposes (Świecka, 2015, pp. 32-33).

Hence, the interest in the mobile channel increased among banks and in subsequent years, banks began to implement their own mobile applications (Świecka, 2015, pp. 32-33, Kaczmarek, 2018, p. 146). Until 2010, only the Raiffeisen Bank offered this kind of application, whereas in 2012 the number of banks offering mobile applications increased to 12 (Hassa, 2013, pp. 42-43). Mobile banking also positively influenced the development of mobile payments technologies - one of them, NFC (Near Field Communication), is based on a developed version of RFID technology and since its first use in mobile devices, it still appears as the most likely line of development of contactless retail payments (Polasik, Wisniewski \& Lightfoot, 2012, p. 212). NFC payments enable making payments on a EFT-POS terminal, with the use of a mobile device (Polasik \& Kumkowska, 2015, p. 103). Since 2012, the possibility of integrating a payment card with a smartphone and making payments using a mobile phone equipped with a special SIM card containing an NFC module, became another feature of mobile banking in Poland (Świecka, 2015, p. 34; Wolna, 2015, p. 163). Less than two years later, the use of an NFC-based payment solution has been somewhat simplified - the Bank Pekao in cooperation with the Mastercard introduced the HCE (Host Card Emulation) solution. It is based on a mobile banking application linked to a personal banking account and offers its customers the possibility of contactless payments without employing a special SIM card (Polasik \& Kumkowska 2015, p. 107; www2). At that time, the research conducted by M. Polasik, J. Górka, G. Wilczewski, J. Kunkowski, K. Przenajkowska and N. Tetkowska (2013, pp. 317-318) has proven, that the contactless payments, including mobile payments are quick, convenient, attractive for customers, and the development of contactless mobile payments including NFC, should be expected.

Together with the increasing number of institutions offering the most upto-date solutions in mobile banking applications and the growing popularity of smartphones, the number of active mobile banking users has been also systematically raising. The figure 1 presents the aforementioned tendency, comparing it at the same time to the number of active users of online banking. The purpose of both channels comparison is to show a decreasing difference between the number of users occurring among mobile and online banking. 
Figure 1. The number of active users of online and mobile banking in 2014-2018 (in millions)

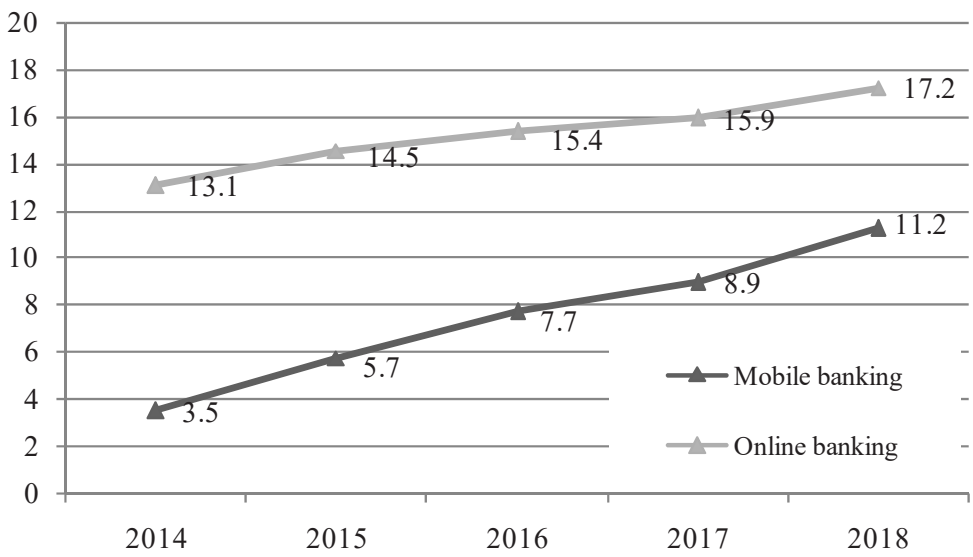

S o u r c e : own study based on: quarterly reports of the Polish Bank Association and the PRNews. $\mathrm{pl}(\mathrm{www} 4)$.

When analyzing the number of active users of mobile and online banking in the years 2014-2018, one can notice a significant decrease of difference occurring between the numbers of users of these two channels. Over the course of five years, the number of online banking users has increased only by $31 \%$, when the number of mobile banking users - by as much as $220 \%$. Both channels maintain an upward trend, which at the same time indicates their continuous development. But, mobile banking develops noticeably faster, which is evidenced by the very dynamic -in comparison to online banking -augmentation of its active users. The pace of mobile banking development may result from the availability on the market of increasingly advanced mobile technology that has been successfully adopted into the widespread use. It could also mean that banks are effectively acquiring new clients or reaching new target groups. In the years 2014-2017, the number of online banking users grew, but slower - the amount of new users was respectively 1.4 million, 0.9 million and 0.5 million in 2017. The reason of this slowdown could be the growing interest in mobile banking, because the number of active users increased on average by 2 million in a given period 2014-2017. In 2018, the number of mobile banking users increased by 2.3 million, thus achieving the highest growth in the entire analyzed period 2014-2018. In turn, the number of online banking users increased in 2018 only by 1.3 million. 
The figure 2 presents the number of active mobile banking users in total and the extracted from it number of active users of mobile banking applications.

Figure 2. The comparison of the number of active mobile banking application users and the number of mobile banking users in total (in millions)

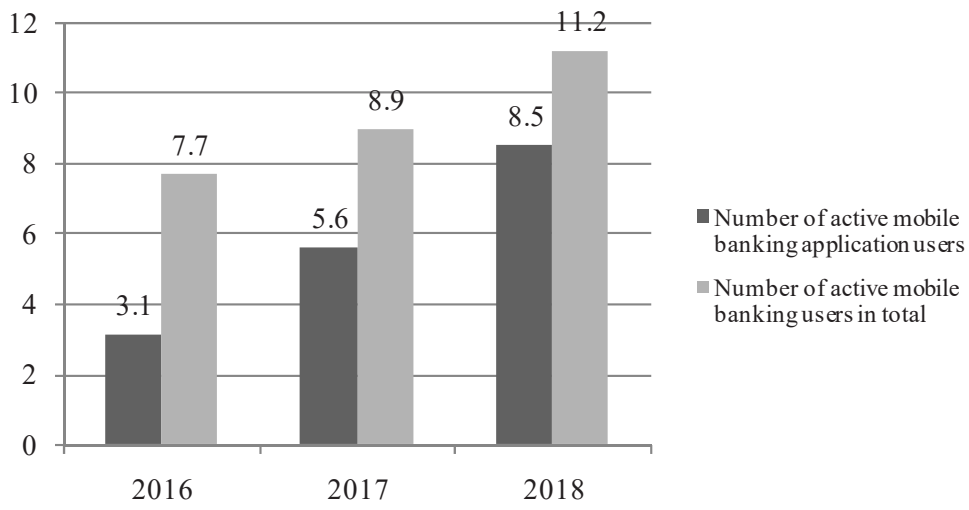

S o u r c e : own study based on: quarterly reports of the PRNews.pl (www4).

In 2016, the share of application users in mobile banking users in total was just over 40\%, then it increased to about 63\% in 2017, and in 2018 the upward trend continued, as already three out of four mobile banking users actively employed bank applications. The growing popularity of mobile banking applications proves its success on the Polish payment services market, since from 2017 it has become the main tool used to carry out individual operations through a mobile channel of communication with the bank. This is related to the increasing quality of the applications offered, which contributes further to the frequency of their usage.

\section{THE SURVEY RESULTS - THE USE OF MOBILE BANKING APPLICATIONS AMONG POLISH INTERNET USERS}

The results of the conducted survey allowed for a more detailed understanding of the popularity of mobile banking applications among Internet users and ranges of services used, along with their preferences regarding mobile banking applications. The results of this survey indicate that these applica- 
tions are already well received by Polish Internet users, as every second respondent makes a use of a bank application installed on his or her smartphone (figure 3).

Figure 3. The popularity of banking mobile applications among Polish Internet users

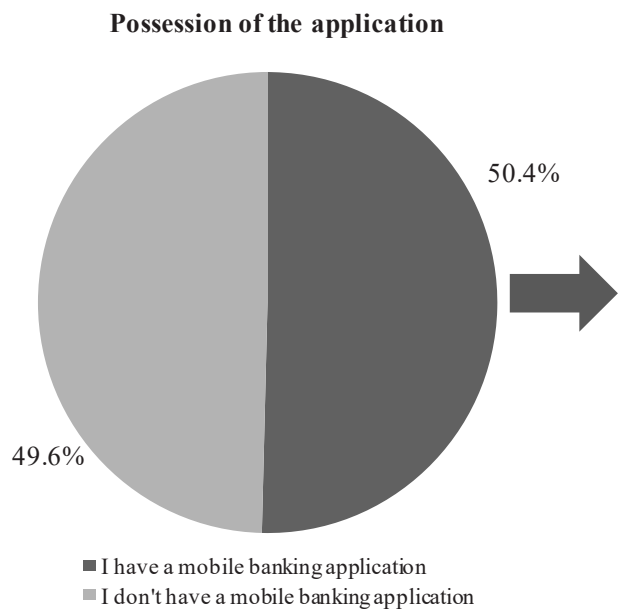

Frequency of the use of the application

S o u r c e : own study: Polish Internet users, 2018, n=1012.

The popularity of the mobile communication channel with the bank is certainly also influenced by the fact that smartphones, due to the number of their functionalities, become a new "digital wallet" for many consumers and nowadays it is easier to forget about a traditional wallet than a personal mobile device.

Currently, the realization of payments via the mobile application becomes easier, and the software also gains on intuitiveness and quickness of operation. These features are certainly the main determinants influencing the regularity and frequency of reaching for the mobile instrument of contact with the bank. Within the research framework respondents were also asked how often they use the mobile application of their bank. It turned out that almost $1 / 3$ of the mobile banking application owners use it on daily basis (figure 3), and almost half of them use it several times a week. Therefore, it can be stated that 
three out of four respondents who have this application use mobile banking intensively.

In the next question, the respondents commented on the selected functionalities of the mobile banking application. According to the figure 4, 91\% of them utilize the possibility of checking the account balance. A slightly smaller percentage of respondents (86\%) make transfers to another bank account. Also the possibility of tracking transaction history proves to be useful, because this functionality is used by 8 out of 10 respondents.

Figure 4. The usage of selected functionalities of mobile banking application

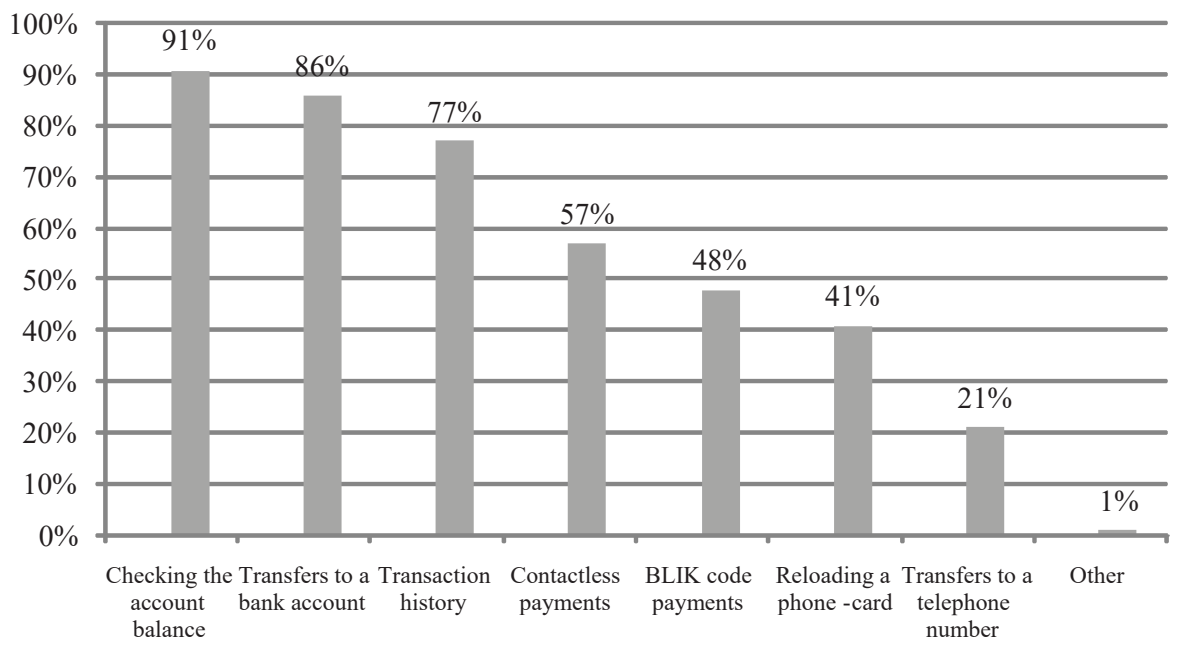

S o u r c e : own study: Mobile banking applications users (among Polish Internet users), 2018, $\mathrm{n}=510$.

It is worth noting that every second owner of a mobile banking application uses mobile payments - $57 \%$ of respondents use contactless payments, while $48 \%$ use the BLIK code for transactions. High percentages of particular functionalities usage suggest that the feature convincing bank clients is the fact that the mobile application is a comprehensive instrument that offers access to many services.

In the final part of this survey, the respondents were asked to describe their sensations related to the use of mobile banking applications. In the questionnaire developed, two groups of questions were distinguished: the first, focused 
on the evaluation of the use of this application, the second on general satisfaction with this application. Through these questions, the authors wanted to examine the respondents' attitude towards mobile banking applications on daily basis.

Figure 5. The perception of mobile banking applications by Polish Internet users*
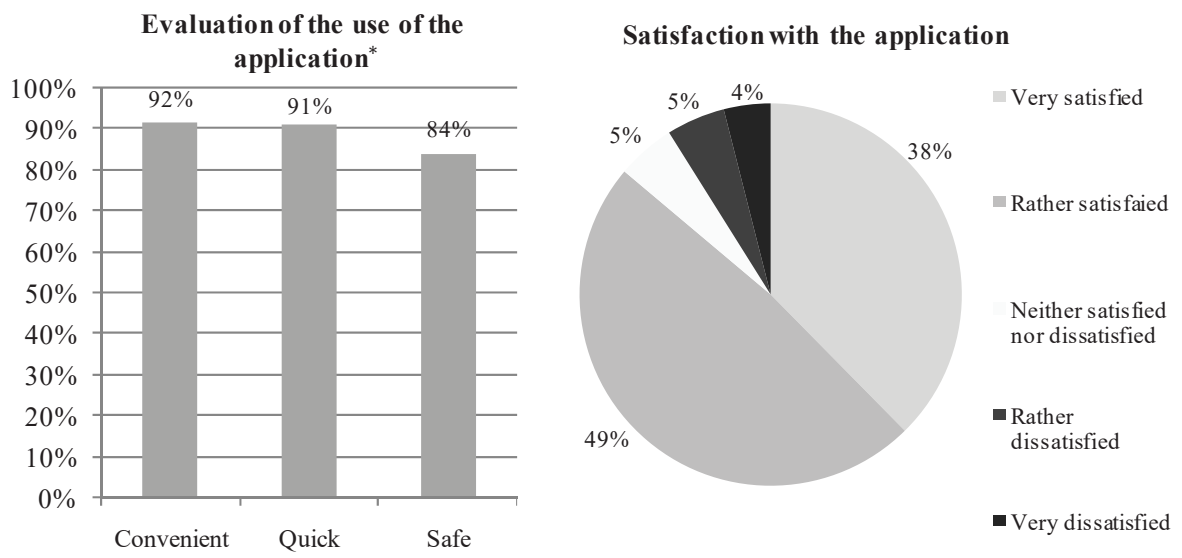

S o u r c e : own study: Mobile banking applications users (among Polish Internet users), 2018, $\mathrm{n}=510 .{ }^{*}$ The results of application use evaluation present the sum of answers "I definitely agree" and "I rather agree".

It turned out that $92 \%$ of respondents opted for the convenience of owned by them mobile banking application, which is probably their main, comfortable communication channel with the bank, and according to $91 \%$ of respondents, these applications are also quick in action, i.e. they do not go down, and transactions can be carried out without unnecessary delays. The security level is not perceived so well, but still very good- $84 \%$ of respondents consider mobile banking as safe, which is certainly influenced by the continuous development of these applications and methods of client authentication.

The last question of this survey was related to assessing the overall satisfaction with using the mobile banking application. Similarly to the evaluation of particular features of the application listed above, the prevailing level of satisfaction is very high - nearly nine out of ten respondents are satisfied with their mobile banking application (figure 5). However, there were negative answers as well, $9 \%$ of respondents are dissatisfied with the application they own. 


\section{CONCLUSIONS}

The popularity of mobile banking in Poland is constantly growing year by year. The number of active mobile banking users in the years 2014-2018 increased by over $220 \%$, and mobile banking is already a standard channel of access to banking products offered by banks. With maintaining the current upward trend in the amount of mobile banking users, the equalization of numbers of people using the mobile and online channels can occur even faster than in the next five years. The current share of active mobile banking applications users among the mobile banking users in total is the highest since introduction of these applications in 2009 to the Polish banking market and reaches 76\%. Moreover, this share attests that mobile applications are the main channel of customer contact with the bank in the area of mobile banking.

During survey conducted for this study, it was established that mobile banking application is already a popular instrument among Polish Internet users, which is indicated by the fact that over half of respondents (50.4\%) have a mobile application installed on their device. Additionally, more than $76 \%$ of them make a use of this application at least several times a week, which indicates a high frequency of using it.

The results indicate that bank customers which are using mobile banking applications apply it very often to control their personal finances (91\% uses it to check the account balance) and to make bank transfers (86\%). An important functionality for the respondents was also access to transaction history (77\%). Moreover, through this application, individual customers are willingly reaching for modern payment methods, i.e. HCE contactless payments (57\%) and payments using the BLIK code (48\%).

Polish Internet users perceive mobile banking applications as a comprehensive instrument, characterized by high convenience and quickness in action. The users of banking applications also consider them to be secure. This high level of perceived safeness (84\%) can be influenced by the continuous development of applications, providing updates of system and security, as well as the possibility of using biometric methods of transaction authorization and logging in selected applications. Furthermore, one can expect that the dynamic acceleration in development of biometrics in banking is approaching, due to legal and technical requirements included in the European Payment Services Directive 2 (Steennot, 2018), which is going to have a positive impact on security level in 
the future, and that will contribute to the perception of the mobile banking applications security.

The level of satisfaction among mobile banking applications users is high around $87 \%$ of respondents is content with his or her mobile application. However, there were negative opinions - banking applications differ in terms of their functionalities, interface transparency and other features, so according to respondents, one of them may be better, while the other one - worse. In this case, it can be concluded that relatively small amount of negative responses regarding satisfaction in reference to mobile banking applications is not an undesirable phenomenon - respondents who are not satisfied, through in-depth research can provide valuable guidance that will enable further development of mobile banking applications in Poland.

To sum up, nowadays the mobile banking applications are comprehensive, more and more popular instrument used for virtual contact with the bank. They are a key element in the development of mobile banking, because handling the banking interface in application on a small device is here much simpler and more convenient in comparison to so called light version of bank websites. Moreover, these applications are also characterized by a high level of ergonomics, as they offer many functionalities in one place. Another thing in favor of mobile banking applications is the ability to download them from mobile stores, i.e. Google Play or AppStore, which provide free access to a given application for all owners of mobile devices (Kaczmarek, 2018, p. 147). In connection with the results of the conducted survey, it can be considered that after several years of presence of banking applications on the Polish payment services market, they have been refined both technically and visually, and customers are satisfied with them, which contributes to high frequency of using them. An example of its success is the IKO mobile banking application, which in February 2019 won the ranking of one hundred best banking mobile applications, beating the solutions of bank giants such as the JP Morgan Chase, the Bank of America or the Barclays (www3). Therefore, it can be predicted that due to the growing needs of customers and the fact that the mobile banking application is now becoming a kind of showcase for the bank, the upward trend in the mobile banking area is likely to continue in the near future, and Polish customers are going to gain access to increasingly improved mobile banking applications. 


\section{REFERENCES}

Alalwan, A.A., Dwivedi, Y.K., Rana, N.P., \& Williams, M.D. (2016). Consumer adoption of mobile banking In Jordan: Examining the role of usefulness, ease of use, perceived risk and self-efficacy. Journal of Enterprise Information Management, 29(1), 118-139. https://dx.doi.org/10.1108/JEIM-04-2015-0035.

Bolibok, P., \& Matras-Bolibok, A. (2014). Bankowość mobilna jako innowacyjny kanał dostępu do usług bankowych. (Mobile banking as an innovative channel of access to banking services.) Roczniki Ekonomii i Zarządzania, (Annals of Economics and Management.) 6(42), no. 2, 7-22.

Davis, F.D. (1989). Perceived usefulness, perceived ease of use, and user acceptance of information technology. MIS Quarterly, 13(3), 319-340. https://dx.doi. org/10.2307/249008.

Hassa, T. (2013). Stan i perspektywy rozwoju bankowości mobilnej dla klientów indywidualnych w Polsce. (The status and prospects for the development of mobile banking for individual clients in Poland.) Zeszyty Naukowe Studia i Prace Kolegium Zarządzania i Finansów, (Studies and Works of the Collegium of Management and Finance.) 138, 39-57.

Kaczmarek, M. (2018). Struktura rynku bankowości mobilnej w Polsce - analiza wybranych wskaźników jego funkcjonowania. (Structure of the mobile banking market in Poland - analysis of selected indicators of its functioning.) Bank i Kredyt, (Bank \& Credit.) 49(2), 145-168.

Krzysztoszek, M. (2017). Bankowość elektroniczna w teorii i praktyce. (Electronic banking in theory and practice.) Komisja Nadzoru Finansowego.

Lee, H., Harindranath, G., Oh, S., \& Kim, D. (2015). Provision of mobile banking services from an actor-network perspective: Implications for convergence and standardization. Technological Forecasting \& Social Change, 90, 551-561.

Polasik, M. (2013). Wykorzystanie elektronicznych kanałów dystrybucji usług bankowych w Polsce. (The use of electronic distribution channel of banking services in Poland.) Copernican Journal of Finance \& Accounting, 2(1), 139-152. https://dx.doi. org/10.12775/CJFA.2013.010.

Polasik, M., Górka, J., Wilczewski, G., Kunkowski, J., Przenajkowska, K., \& Tetkowska, N. (2013). Time efficiency of Point-of-Sale payment methods: Empirical results for cash, cards and mobile payments. Lecture Notes in Business Information Processing, 141, 306-320. https://dx.doi.org/10.1007/978-3-642-40654-6_19.

Polasik, M., \& Kumkowska, N. (2015). Determinanty zainteresowania płatnościami mobilnymi ze strony polskich konsumentów. (Determinants of Interest in Mobile Payments among Polish Consumers.) Problemy Zarzadzania, (Management Problems.) 13(3), 102-117. https://dx.doi.org/10.7172/1644-9584.54.7.

Polasik, M., Wisniewski, T.P., \& Lightfoot, G. (2012). Modelling customers' intentions to use contactless cards. International Journal of Banking, Accounting and Finance, 4(3), 203-231. https://dx.doi.org/10.1504/IJBAAF.2012.051590.

Shaikh, A.A., \& Karjaluoto, H. (2015). Mobile banking adaption: A literature review. Telematics and Informatics, 32, 129-142. 
Sobiesiak, M., \& Zagrodniczek, P. (2018). Nowe zagrożenia a metody ochrony usług finansowych w sektorze bankowości mobilnej na przykładzie studentów lubelskich uczelni. (New threats and methods of protection of financial services in the mobile banking sector.) Journal of Finance and Financial Law, 2(18), 65-78.

Steennot, R. (2018). Reduced payer's liability for unauthorized payment transactions under the second Payment Services Directive (PSD2). Computer Law \& Security Review, 34(4), 954-964. https://dx.doi.org/10.1016/j.clsr.2018.05.008.

Polish Bank Association. NetB@nk reports, https://zbp.pl/raporty/raport-netb-nk (accessed: 20.05.2019).

Świecka, B. (2015). Płatności mobilne jako innowacje na rynku detalicznych płatności bezgotówkowych. (Mobile Payments as Innovations on the Retail Cashless Payments Market.) Problemy Zarządzania, (Management Problems.) 3(54), 29-40. http://dx.doi.org/10.7172/1644-9584.54.2.

Wojtacka-Pawlak, K. (2015). Ewolucja bankowości internetowej w Polsce w ujęciu czteroetapowym. (The evolution of online banking in Poland in four stages.) Zeszyty Naukowe Uniwersytetu Ekonomicznego w Katowicach, (Scientific Papers of the University in Economics in Katowice.) 239, 153-161.

Wolna, J. (2015). Rozwój systemów płatności mobilnych w Polsce. (The development of mobile payments systems in Poland.) Zeszyty Naukowe Uniwersytetu Ekonomicznego w Katowicach, (Scientific Papers of the University in Economics in Katowice.) 239, 162-180.

Zakonnik, Ł., \& Dembowski, P. (2018). Bezpieczeństwo bankowości internetowej w Polsce na przestrzeni lat 2002-2017 - przegląd rozwiązań oferowanych klientom indywidualnym. (Internet banking security in Poland in the last 15 years - a review of the solutions offered to individual clients.) Zeszyty Naukowe Uniwersytetu Ekonomicznego w Katowicach, (Scientific Papers of the University in Economics in Katowice.) 355, 104-116.

Zarańska, K., \& Zborowski, M. (2018). Charakterystyka bankowości elektronicznej. (Characteristics of electronic banking.) In A. Gospodarowicz (Ed.). Bankowość elektroniczna. Istota i innowacje. (Electronic banking. Essence and innovations.) Warszawa: C.H. Beck.

(www1) Historia bankowości mobilnej w Polsce, (History of mobile banking in Poland.) https://www.bankier.pl/wiadomosc/Historia-bankowosci-mobilnej-w-Polsce-7284816.html (accessed: 19.05.2019).

(www2) Jak powstały płatności HCE. Oto krótka historia wynalazku, który ma szansę odesłać plastikową kartę do lamusa, (How HCE payments were developed. A brief history of the invention, which has a chance to send the plastic card to the past.) https://www.cashless.pl/4194-jak-powstaly-platnosci-hce-oto-krotkahistoria-wynalazku-ktory-ma-szanse-odeslac-plastikowa-karte-do-lamusa (accessed: 19.05.2019).

(www3) IKO najlepszą mobilną aplikacją na świecie. Sukces PKO Banku Polskiego, (IKO is the best mobile application in the world. The success of PKO Bank Polski.) https:// www.money.pl/gospodarka/iko-najlepsza-mobilna-aplikacja-na-swiecie-sukcespko-banku-polskiego-6348711245523073a.html (accessed: 21.05.2019). 
(www4) Mobile banking reports, https://prnews.pl/raporty/bankowosc-mobilna (accessed: 20.05.2019).

(www5) SIM Toolkit, czyli bank w komórce, (SIM Toolkit, in other words a bank in a cellphone.) https://prnews.pl/sim-toolkit-czyli-bank-w-komorce-71805 (accessed: 20.05.2019). 